\title{
IMPROVING BASIC TEACHING SKILLS OF PRE-SERVICE TEACHER OF ISLAMIC RELIGIOUS EDUCATION TEACHERS WITH PROJECT BASED LEARNING STRATEGIES IN THE PANDEMIC PERIOD
}

\author{
Fatma Sukmawati \\ Department of Islamic Education, Faculty of Tarbiyah, Institut Islam Mamba'ul 'Ulum Surakarta \\ Sadewa Street No.14 Surakarta, Central Java, Indonesia. 57155 \\ Email: fatmasukma76@gmail.com
}

\begin{abstract}
The basic teaching skills of pre-service of teacher Islamic religious education who have not been optimal have caused a decrease in the quality of the actual implementation of field teaching practices. The purpose of this study was to improve the teaching skills of Pre-service teacher of Islamic religious education teachers using the Project Based Learning strategy during the Pandemic. This type of research uses Classroom Action Research (CAR). The research subjects were 65 people. Data collection techniques using observation. The results showed that through the use of project based learning strategies to improve basic teaching skills with an average value of 72 in cycle 1 and an average value of 83.4 in cycle 2. For future research, it is recommended that the application of teaching practice practice should apply all basic teaching skills with some practice times with sufficient time estimation, as well as assessments carried out by learning experts.
\end{abstract}

Keywords: basic teaching skills, Islamic religious education, project based learning

\begin{abstract}
Abstrak: Keterampilan dasar mengajar pada mahasiswa calon guru pendidikan agama Islam yang belum optimal menyebabkan menurunnya kualitas pelaksanaan praktek mengajar lapangan yang sesungguhnya. Tujuan penelitian ini adalah untuk meningkatkan keterampilan mengajar pada mahasiswa calon guru pendidikan agama Islam menggunakan strategi Project Based Learning di masa pandemi. Jenis penelitian menggunakan Penelitian Tindakan Kelas (PTK). Subjek penelitian sebanyak 65 orang. Teknik pengumpulan data menggunakan observasi. Hasil penelitian menunjukkan melalui penggunaan strategi project based learning meningkatkan keterampilan dasar mengajar dengan nilai rata-rata 72 siklus I dan nilai rata-rata 83,4 pada siklus II. Bagi penelitian berikutnya disarankan agar penerapan praktek latihan mengajar hendaknya menerapkan semua keterampilan dasar mengajar dengan beberapa kali latihan dengan estimasi waktu yang cukup, serta penilaian dilakukan oleh ahli pembelajaran.
\end{abstract}

Kata Kunci: keterampilan dasar mengajar, pendidikan agama Islam, project based learning

\section{Introduction}

Universities have an important role in producing professional and qualified teacher candidates. Through college, students study scientific fields according to their interests. There are several differences in the content of the material in educational courses because they must be adapted to each scientific field. For example, in the Islamic religious education study program, a Pre-service teacher of Islamic religious education must understand the science of Islam. Not only that, as a prospective teacher of Islamic religious education, besides having to understand the concept of the material well, connecting the material with the daily life of students, and instilling good values in students. Pre-service teacher must have the skills to explain to students so that their knowledge can be well received by students. In order for prospective Islamic religious education teachers to be able to do this well, the right method or method is needed to be used in the learning process. The method is a basic teaching skill. Pre-service teacher of Islamic religious education teachers are required to be able to understand and apply basic teaching skills in order to teach well in front of the class.

Skills are the ability to use reason, ideas, and creativity in doing, making or changing something to be more meaningful so that it can produce an added value from the results that are done. In particular, skills in teaching are a way used to express opinions, defend, and express knowledge and is a way to solve problems (Mansyur, 2017). Basic teaching skills are skills that must be mastered by every teacher. Or teacher candidates. Basic teaching skills are very important to be mastered by teachers, especially to 
create a dynamic learning atmosphere, so educators must plan things that can make students interested and mentally prepared to participate in the learning process, so that it has a positive effect on learning activities. Regarding this, teachers must master basic teaching skills (Hidayat, 2016).

According to research conducted by Supriyanto (2019), basic teaching skills play a very important role in the success of teaching and learning activities such as questioning skills, reinforcement skills, variation skills, explaining skills, opening and closing lessons, skills guiding small group discussions, and skills manage classes. In addition, it explains that in the learning process students are required to practice in order to increase self-confidence, good planning and self-regulation in order to achieve high learning outcomes. These basic teaching skills must be mastered well by prospective Islamic religious education teachers without exception. Between one skill with another skill are interrelated and mutually support each other. For example, the skill of opening lessons is related to the skills of explaining and managing the class, because when a teacher is about to start a lesson, he must provide a reference or link to the previous material and must also condition the class in advance so that it is ready to receive lessons. In opening learning the teacher provides motivation so that students are interested in the material that will be delivered by the teacher so that the class will be easy to condition. On the other hand, if the teacher is less skilled in opening learning, then classroom conditioning will also be difficult to do. Basic teaching skills are the skills of a teacher in deciphering the concepts of learning materials in the classroom (Nurwahidah, 2020).

Activities in applying teaching skills are carried out in microteching courses carried out on Semester VI students of the Islamic Religious Education S1 Study Program for the 2020/2021 Academic Year, Tarbiyah Faculty, Islamic Institute of Mambaul Ulum Surakarta. The lecture process begins with an explanation of the material regarding basic teaching skills. From these activities, it turned out that students were still busy themselves with personal activities without listening to the activities carried out during the delivery of the material, during the question and answer process there were still some students who did not understand the concept of teaching skills that had been described previously, there were also student responses who were still shy in giving examples. some skills during the learning process. This is an evaluation material so that teaching skills can be mastered by prospective teacher students and students can apply skills in teaching practice during the lecture process.

One of the causes of the low teaching skills of prospective teacher students is due to the lack of variation in learning strategies. Learning strategies so far are still lectures and questions and answers, even though to apply teaching skills it is necessary to use a method that is centered on improving skills, and requires strategies that apply collaboration and practice or exercises that can be done repeatedly in applying teaching skills. In this current pandemic, learning must be done online. Online learning will be meaningful if the synergy between strategies and learning methods is right. One suitable learning strategy in online learning is project-based learning. The implementation of a strategy that is believed to be an alternative in improving teaching skills by using a Project Based Learning strategy. Project Based Learning strategy is able to apply teaching skills because in its application it uses a practical process, works collaboratively and produces a product so that it is believed to be able to strengthen a concept and refine skills through serious practice (Kokotsaki et al., 2016).

The main component of project-based learning is posing problems that are presented to compiling and starting activities that emphasize a number of projects until the final result is a product as a series of individual communication activities or various task results. Project-based learning provides opportunities for students to learn concepts in depth while also improving their teaching skills. As stated by Tertemiz, (2012) project-based learning is an investigation of topics from the real world. A well-designed project asks students to tackle real problems and important issues that occur in everyday life, especially in the learning process. Thus, the projects that students build are based on observations of real-world problems around them that will provide meaning for them.

Based on this, it is necessary to have effective learning applied to students to improve their teaching skills. Moreover, due to the impact of the pandemic that hit so that learning did not run 
optimally because they had to stay at home and implement physical distancing. So that online learning with a project based learning strategy is one solution to the problems faced to answer this problem.

\section{Materials and Methods}

This research is a classroom action research. The research subjects were 65 students of the Islamic Education Study Program, Faculty of Tarbiyah, Islamic Institute of Mambaul Ulum Surakarta in the 2020/2021 academic year. This research was conducted in the 6th semester of microteaching course. This action research uses two cycles, cycle I with three meetings and cycle II with three meetings. If the first cycle has not been achieved, it will be continued in the second cycle and so on until the research objectives are achieved. The instruments used in this study were syllabus, lesson plans, and a basic teaching skills assessment questionnaire. In this study, the basic teaching skills studied were: opening lesson skills, closing lessons, explaining skills, variation skills and questioning skills.

Method of data collection is done through the technique of testing, observation and documentation. The data collection techniques used are: (a) observation, and documentation. Observations used are systematic observations, namely observations made by observers using guidelines as an instrument of observation. The instruments used in this study were: observation sheets and documentation. The observation sheets were used by researchers as a guide to make observations or observations in order to obtain accurate data in observations.

\section{Result and Discussion}

The results showed that the use of the Project Based Learning strategy could improve the basic teaching skills of prospective Islamic religious education teacher students with a final overall score of 75. The results of the data analysis in this study aimed to see the process of implementing the Project Based Learning strategy in improving the basic teaching skills of prospective students. Islamic religious education teacher. The results of the assessment of improving basic teaching skills by applying project based learning strategies in cycle I and cycle II can be seen in the following Table 1.

Table 1. Peer assessment of basic teaching skills cycle 1

\begin{tabular}{lc}
\hline Basic Teaching Skills & Score \\
\hline Skills Opening lessons & 80 \\
Closing Skills & 70 \\
Variation Skills & 78 \\
Explaining Skills & 72 \\
Questioning Skills & 75 \\
Average Score & $\mathbf{7 5}$ \\
\hline
\end{tabular}

The results of the next assessment are carried out in the second cycle which can be seen in Table 2 below:

Table 2. Peer assessment of basic teaching skills cycle II

\begin{tabular}{lc}
\hline Basic Teaching Skills & Score \\
\hline Skills Opening lessons & 82 \\
Closing Skills & 88 \\
Variation Skills & 80 \\
Explaining Skills & 85 \\
Questioning Skills & 82 \\
Average Score & $\mathbf{8 3 , 4}$ \\
\hline
\end{tabular}

According to the results of Tables 1 and 2, peer assessment of basic teaching skills in cycle 1 and 2 can be categorized as follows Tabel 3. 
Tabel 3. Category and score

\begin{tabular}{cc}
\hline Score & Category \\
\hline $85-100$ & Very good \\
$75-84$ & Good \\
$74-65$ & Enough \\
$64-59$ & Less \\
\hline
\end{tabular}

Based on the table above, it can be concluded that the implementation of teaching skills training with the types of skills opening and closing lessons, explaining skills, questioning skills, and variation skills carried out in the first cycle in general teaching skills in the good category (B) with an average of 75 and the second cycle in general, teaching skills are in the good category (B) with an average of 83,4. The results of the cumulative assessment of the process of improving teaching skills through Project Based Learning strategies that have been carried out in the first and second cycles are presented in the following Table 4.

Table 4: Recapitulation of basic teaching skills

\begin{tabular}{lccc}
\hline \multirow{2}{*}{ Basic teaching skills } & \multicolumn{2}{c}{ Cycle } & \multirow{2}{*}{ Information } \\
\cline { 2 - 3 } & I & II & Increase \\
Skills Opening lessons & 80 & 82 & Increase \\
Closing Skills & 70 & 88 & Increase \\
Variation Skills & 78 & 80 & Increase \\
Explaining Skills & 72 & 85 & Increase \\
Questioning Skills & 75 & $\mathbf{8 3 , 4}$ & Increase \\
Average Score & $\mathbf{7 5 , 0}$ & & \\
\hline
\end{tabular}

From Table 4, it can be seen that the basic teaching abilities of prospective Islamic religious education teacher students in the first and second cycles using the Project Based Learning strategy have increased. It can be concluded that this research can be said to be successful because the prospective teacher students have exceeded the success indicator by $75 \%$. So it can be said that the use of project based learning strategies can improve teaching skills in prospective students of Islamic religious education teachers.

This classroom action research focuses on improving the basic teaching skills of prospective Islamic religious education teacher students which consists of several skills including: 1) Opening skills, 2) Closing lessons, 3) Explaining skills, 4) Variation skills and 5) Skills asking. The results of this classroom action research are able to improve some basic teaching skills, namely: Opening skills are the initial activities carried out by teachers in learning activities with the aim of preparing students mentally to be satisfied with the things to be learned (Sundari, Fitri and Muliyawati, 2017). In this study, the skill of opening lessons has increased. In the process of teaching training students, prospective teachers of Islamic Religious Education have implemented several skills in opening lessons, as indicated by the motivation of students in following lessons and creating an atmosphere that fosters children's attention to the teaching and learning process.

The skill of closing the lesson is the teacher's activity to end the learning activity. The purpose of closing the lesson is to provide a comprehensive picture of what is learned, to find out the extent to which children's understanding of the material has been studied and the level of success of educators in the learning process. In closing the lesson skills have increased this can be seen when the teaching practice process students have applied several skills during the closing stages of the lesson, it appears that students are able to encourage children to complete all the learning processes that have been carried out and apply some reinforcement to the work of children who are already good and that need to be done. improved. This is further supported by the results of research, an increase from the value of 70 in the first cycle to 88 in the second cycle.

The skill of conducting variations is a teacher activity to change learning which includes teaching styles, use of learning media, patterns of interaction with children, and stimulation (Lestari, 2018). In this study, teacher activities in doing variations have increased this can be seen from the interaction 
between students and educators, using varied teaching styles, and using learning media. This is further supported by the results of research that there is an increase from the value of 78 in the first cycle to 80 in the second cycle.

The skill of explaining is an activity carried out by educators in conveying information to children. This activity is an activity that is often carried out by educators. The activity of explaining means organizing learning material in a systematically planned order so that it can be easily understood by children (Nurwahidah, 2020). In this class action research, the ability to explain has increased, this can be shown when the teaching practice process, educators master the material to be taught. In addition, educators explain the material in easy-to-understand language, so that students focus on the material being studied. This is further supported by the results of research that there is an increase from the value of 72 in the first cycle to 85 in the second cycle.

Questioning skills are the teacher's way of involving students to participate in answering the teacher's questions in the learning process (Mulyatun, 2014). The following components of questioning skills are: 1) focusing attention, 2) clear and concise questions, 3) providing references, 4) distributing questions, 5) giving time to think. Basic questioning skills have increased this can be seen from the enthusiasm of students so that they focus on the questions expressed by students. This is further supported by the results of research that there is a decrease from the value of 75 in the first cycle to 82 in the second cycle.

In this study, the selection of the Project Based Learning strategy is based on the ability to apply teaching skills during the pandemic, because in its application it produces products in the form of teaching practice videos and repeated exercises so that it is believed to strengthen a concept and refine basic teaching skills. Project Based Learning strategies in improving basic teaching skills require activities such as planning projects, working on complex tasks, and assessing student performance and progress. Project based learning strategy is a learning strategy that is suitable for use in learning activities during the pandemic because through project based learning students are invited to collaborate, be independent and explore (Nuryati et al., 2020). The implementation of the Project Based Learning strategy has a relationship in improving teaching skills because of the direct practice process. So that the implementation of the Project Based Learning Strategy is believed to be able to improve the teaching skills of prospective students of Islamic religious education teachers.

In practice, activities in carrying out basic teaching skills are adjusted to the pandemic situation that is being experienced with the Covid-19 pandemic situation, so learning is carried out online. Since in this pandemic era students cannot practice teaching, they practice in their respective places and record it in the form of videos, then the product in the form of teaching practice videos is uploaded to YouTube. To help overcome this situation, the lecturer in the microteaching course then applies the Project Based Learning strategy. Student teacher candidates set up their classes at home and practice teaching by applying basic teaching skills.

The stages of project-based learning carried out in this study consisted of orientation, defining and identifying projects, planning projects, implementing projects, reporting projects, and evaluating project results (Alacapinar, 2008). At the student orientation stage, prospective teachers will get initial questions as a stimulus before entering the subject matter. At this orientation stage, students also gain knowledge through multimedia which contains subject matter as an initial provision for students to enter the subject matter. Multimedia that is used as a tool can increase students' understanding of learning materials. Then in the next stage, prospective teacher students identify the project to be implemented, at this stage they are invited to choose the project to be carried out and determine the source that will be used as a reference for students to answer the problems of the project being worked on (Çakıroğlu, 2014). In this study, the sources used as reference materials in the project were print media, electronic media, and the results of interviews with resource persons such as teachers or lecturers. The third stage is planning the project, at this stage the prospective teacher students will plan what activities will be carried out, the time, tools and materials, resources needed in carrying out the selected project. In the fourth stage, namely project implementation, student teacher candidates begin to carry out project activities according to the plans made in the previous stage. The fifth stage is reporting the results of 
projects that have been carried out by students. The project results are in the form of micro teaching practice videos uploaded on YouTube.

The implementation of the Project Based Learning Strategy in developing teaching skills for prospective teacher students has a positive effect, this is supported by the enthusiasm of students in practicing the eight teaching skills carried out at home. The skills that have been improved in teaching include: 1) Opening skills, 2) Closing lessons, 3) Explaining skills, 4) Variation skills, and 5) Questioning skills.

Through the implementation of the project based learning strategy, it involves student teacher candidates in understanding every teaching step such as teaching practice activities, discussions with lecturers by sending project results and asking questions related to the project. Problems that you want to ask can be submitted directly through Google meet, so that prospective teacher students can solve or answer these problems before the lecturer gives an answer. This is in accordance with the steps in the Project Based Learning strategy in the monitoring step which is the teacher's responsibility for the activities of students in carrying out projects. Teachers can provide guidance at each stage of the project being carried out then provide input and advice to students if there are problems in working on the project (Arizona et al., 2020).

\section{Conclusion}

The teaching skills of prospective Islamic religious education teacher students have increased after implementing the Project Based Learning strategy. This can be seen from the results of the assessment of teaching skills which consist of: 1) Opening skills, 2) Closing lessons, 3) Explaining skills, 4) Variation skills, 5) Questioning skills. The implementation of project based learning strategies can improve the teaching skills of Semester VI students of Islamic Religious Education Study Program, Faculty of Tarbiyah, Islamic Institute of Mambaul Ulum Surakarta for the 2020/2021 academic year. The improvement of students' teaching skills has increased due to the process of understanding a material in depth regarding teaching skills, direct practice for each student is carried out at home, skill development is carried out repeatedly for every aspect of skills, and at the end of learning there is an evaluation of the results of practical products. teaching skills. For future research, it is suggested that the application of teaching practice practice should apply all basic teaching skills with several exercises with sufficient time estimation, and assessments carried out by learning experts.

\section{References}

Alacapinar, F. 2008. Effectiveness of project-based learning. Eurasian Journal of Educational Research 8: 17-34.

Arizona, K., Abidin, Z., \& Rumansyah, R. 2020. Pembelajaran online berbasis proyek salah satu solusi kegiatan belajar mengajar di tengah pandemi Covid-19. Jurnal Ilmiah Profesi Pendidikan 5(1): 64-70. https://doi.org/10.29303/jipp. v5i1.111.

Çakıroğlu, Ü. 2014. Enriching project-based learning environments with virtual manipulatives: A Comparative study. Eurasian Journal of Educational Research 55: 201-222. https://doi.org/10.14689/ejer.2014.55.12.

Hidayat, H. S. 2016. Hubungan minat terhadap profesi guru dan motivasi berprestasi dengan keterampilan mengajar. Jurnal Pendidikan dan Kebudayaan 14(75): 1140-1154. https://doi.org/10.24832/jpnk.v14i75.375.

Kokotsaki, D., Menzies, V., \& Wiggins, A. 2016. Project-based learning: A Review of the literature. improving schools 19(3): 267-277. https://doi.org/10.1177/1365480216659733.

Mansyur. 2017. Keterampilan dasar mengajar dan penguasaan kompetensi guru (Suatu proses pembelajaran micro). ElGhiroh 21(1): 130-146.

Mulyatun. 2014. Analisis keterampilan dasar mengajar mahasiswa calon guru kimia (Studi pada praktik pengalaman lapangan mahasiswa Tadris Kimia). Jurnal Phenomenon 4(1): 79-90.

Nurwahidah, I. 2020. Kemampuan keterampilan dasar mengajar mahasiswa calon guru IPA Program Studi Pendidian IPA. EduTeach: Jurnal Edukasi dan Teknologi Pembelajaran 1(2): 22-33. https://doi.org/10.37859/eduteach.v1i2.1957.

Nuryati, D. W., Masitoh, S., \& Arianto, F. 2020. Pengaruh project based learning terhadap kreativitas peserta didik di masa pandemi. Educate : Jurnal Teknologi Pendidikan, 5(2), 98-106. https://doi.org/10.32832/educate.v5i2.3375 .

Sundari, Fitri \& Muliyawati, Y. 2017. Analisis kepuasan mahasiswa terhadap kinerja dosen Program Studi Pendidikan Guru Sekolah Dasar Universitas Pakuan. Pedagonal: Jurnal Ilmiah Pendidikan 1(1): 26-36. 
Supriyanto, Y. S. H. 2019. Meningkatkan keterampilan mengajar melalui pengembangan microteaching berbasis experiential learning melalui peran kelompok dan model. JPEKA: Jurnal Pendidikan Ekonomi, Managemen dan Keuangan 3(1): 33-46. https://doi.org/DOI: 10.26740/jpeka.v3n1.p33-46.

Tertemiz, N. 2012. The effects of project- and activity-supported practiceson mathematics education achievement and student views. Egitim Arastirmalari - Eurasian Journal of Educational Research 46: 159-178.

Wahyulestari, M. R.D. 2018. Keterampilan dasar mengajar di Sekolah Dasar. Prosiding Seminar Nasional Pendidikan Era Evolusi "Membangun Sinergitas dalam Penguatan Pendidikan Karakter Era IR 4.0": 199-210. 